\title{
Diets of five important predatory mesopelagic fishes of the central North Pacific
}

\author{
C. Anela Choy ${ }^{1, *}$, Elan Portner ${ }^{1}$, Mia Iwane ${ }^{2}$, Jeffrey C. Drazen ${ }^{1}$ \\ ${ }^{1}$ Department of Oceanography, University of Hawaii, 1000 Pope Road, Honolulu, Hawaii 96822, USA \\ ${ }^{2}$ Rosenstiel School of Marine and Atmospheric Science, University of Miami, 1320 South Dixie Highway, Coral Gables, \\ Florida 33124, USA
}

\begin{abstract}
The diets of 5 large predatory mesopelagic fishes-Alepisaurus ferox (longnosed lancetfish), Gempylus serpens (snake mackerel), Lepidocybium flavobrunneum (Smith's escolar), and Lampris spp. (big-eye and small-eye opah, or moonfish) - from the central North Pacific Ocean (around Hawaii) were examined $(\mathrm{n}=430$, all species combined), most for the first time. Recent analysis of fishery data has shown that many of these species have been undergoing decadal increases in abundance, suggesting system-wide changes. A. ferox diet was numerically dominated by hyperiid amphipods from 3 genera (Phrosina, Phronima, Platyscelus; $37 \% \mathrm{~N}$ ), pelagic polychaete worms, mesopelagic fishes (including young A. ferox size classes), and cephalopods. G. serpens fed primarily on epipelagic fishes (exocoetids, molids) and ommastrephid squids. Diets of the 2 Lampris species were the most similar to one another, consisting of large numbers and frequent occurrences of the onychoteuthid squid Walvisteuthis youngorum and a diverse assemblage of epipelagic and mesopelagic fishes. More than $90 \%$ of the L. flavobruneum stomachs were without food items; small numbers of prey identified included the ommastrephid squid Sthenoteuthis oualaniensis, aristeid shrimps, and unidentified fishes. The diet descriptions support the idea that these predatory fishes carve out unique ecological niches in the pelagic environment by exploiting unique components of micronekton communities across epipelagic and mesopelagic depth zones. Adult size classes of tunas and billfishes occupying a shared vertical habitat do not appear to compete for prey resources to any great extent, perhaps allowing for successful partitioning of limited prey resources within an oligotrophic gyre ecosystem.
\end{abstract}

KEY WORDS: North Pacific Subtropical Gyre - Opah - Snake mackerel - Lancetfish · Escolar · Stomach content analysis $\cdot$ Ecological niche partitioning

\section{INTRODUCTION}

Large mobile pelagic fishes play a key predatory role in subtropical ocean systems by consuming animals of intermediate trophic levels, namely abundant and diverse zooplankton and micronekton that are the trophic links to primary producers. Commercial longline fisheries operating in offshore waters of the North Pacific Subtropical Gyre (NPSG) regularly harvest several species of tunas and billfishes, along with numerous non-target species of large pelagic

*Email: cachoy@hawaii.edu fishes such as gempylids and alepisaurids (Boggs \& Ito 1993, Polovina et al. 2009). Recent analysis of fishery catch data from the Hawaii-based longline fishery suggests that there is evidence for long-term shifts in abundance at or near the top of the NPSG pelagic food web. Over the period 1996 to 2006, there have been clear increases in the relative abundances of non-target pelagic fishes, while apex predators such as sharks and large tunas have declined (Polovina et al. 2009). Furthermore, longline fishery efforts in the NPSG are thought to have caused substantial

() The authors 2013. Open Access under Creative Commons by Attribution Licence. Use, distribution and reproduction are unrestricted. Authors and original publication must be credited. 
changes in the long-term size structure of pelagic predatory fishes, with large species (>15 kg) significantly decreasing in catch $(\sim 50 \%)$, while small species $(<15 \mathrm{~kg})$ have concurrently increased $\sim 25 \%$ (Polovina \& Woodworth-Jefcoats 2013). Understanding the causes for these population changes is hampered by a lack of diet data for many of the non-target pelagic species, which could aid in understanding interspecific interactions.

There are 5 species that are abundantly captured in the Hawaii-based longline fishery in the NPSG: longnosed lancetfish Alepisaurus ferox, snake mackerel Gempylus serpens, moonfish or opah (Lampris sp. big-eye and Lampris sp. small-eye; J. Hyde pers. comm.), and Smith's escolar Lepidocybium flavobrunneum. Despite being globally distributed throughout tropical and subtropical marine ecosystems with potentially high abundances, very little is known about the basic biology and trophic ecology of these large fishes. Incomplete anecdotal observations lend to the common conception that these species are all mesopelagic predators that feed on a diversity of midwater fishes, crustaceans, and cephalopods (e.g. Nakamura \& Parin 1993). The term 'mesopelagic predator' could refer to these fishes inhabiting the mesopelagic zone (waters below the euphotic zone and above the light extinction depth, generally $\sim 200$ to $1000 \mathrm{~m}$ ), and/or the tendency to prey on animals inhabiting the mesopelagic zone. To date there are no peer-reviewed diet studies for snake mackerel, Smith's escolar or the 2 tropical species of opah. However, a single study from the Southern Ocean details the dietary preferences of the southern opah Lampris immaculatus (Jackson et al. 2000b).

Information on the vertical habitat utilization of these species is also quite limiting, but, augmenting the scarce diet data for these species, recent tagging observations have shown mesopelagic depth preferences for opah and Smith's escolar, with excursions to epipelagic waters that fit classic diel vertical migration (DVM) patterns in the pelagic environment. Opah tagged in the NPSG have been shown to utilize the upper mesopelagic waters, exhibiting DVM whereby they occupy average depths of $\sim 100$ to $400 \mathrm{~m}$ during the day with excursions to at least $736 \mathrm{~m}$, and come up to $\sim 50$ to $150 \mathrm{~m}$ at night (Polovina et al. 2008). Tagging data from only 1 specimen of Smith's escolar has been reported in the literature and showed movement throughout the entire epipelagic and mesopelagic zones, 0 to $1000 \mathrm{~m}$, with some indication of DVM (Kerstetter et al. 2008). Tagging information has not been reported for lancetfish or snake mackerel, but these species are commonly caught on both shallow and deep longline sets deployed in waters $\sim 0$ to $400 \mathrm{~m}$ deep in the NPSG. Snake mackerel and lancetfish in this study were most frequently caught on deep longline sets deployed during daylight hours and hauled up during late afternoon and early evening hours, in support of mesopelagic habitat preferences. Furthermore, with the exception of snake mackerel, these species lack morphological attributes of epipelagic animals (e.g. countershading), instead showing deep red or black coloration that is characteristic of mesopelagic inhabitants.

Lancetfish is the one species for which diet data is available. Several studies report dietary preferences from the Pacific Ocean (Haedrich \& Nielsen 1966, Kubota \& Uyeno 1970, Okutani \& Tsukada 1988, Moteki et al. 1993, 2001, Young et al. 2010), with brief notes from the Indian (e.g. Potier et al. 2007a,b, Romanov et al. 2008) and Atlantic Oceans (e.g. Satoh 2004, Cherel et al. 2007). Lancetfish are generally characterized as opportunistic predators that feed on a diversity of mesopelagic micronekton fishes (e.g. Sternoptyx spp., paralepidids, Anoplogaster cornuta), cephalopods and crustaceans, and a diversity of zooplankton (heteropods, pteropods, polychaetes) (Haedrich \& Nielsen 1966, Moteki et al. 1993).

To begin to understand potential competitive interactions between these mid-trophic species and commercially valuable tunas and billfishes, more direct data is needed to describe their diets. With the help of the National Marine Fisheries Service and fishery observers aboard Hawaii-based longline vessels, we opportunistically collected stomach samples over several years and across a large region of the central North Pacific Ocean. Our primary goal was to provide general diet descriptions and thus attempt to interpret the trophic roles of 5 species of understudied but important pelagic fish predators of the NPSG: longnosed lancetfish, snake mackerel, big-eye opah, small-eye opah, and Smith's escolar.

\section{MATERIALS AND METHODS}

\section{Sample collection and processing}

Pelagic fish stomachs were opportunistically collected at sea by trained longline fishery observers of the National Oceanic and Atmospheric Administration's (NOAA) Pacific Islands Regional Observer Program during 2007 to 2012 (as described in Choy et al. 2009) (Table 1). The majority of samples were col- 
Table 1. Mesopelagic predatory fish species examined for stomach contents in the North Pacific Subtropical Gyre during 2007 to 2012. Also included are predator species codes, total numbers of stomachs examined (N) and numbers of those containing food items, predator lengths (forklength in $\mathrm{cm}$ ) and masses (whole body mass in $\mathrm{kg}$, where available) for all specimens examined, and the percent of total stomachs containing longline fishery bait

\begin{tabular}{|c|c|c|c|c|c|c|c|c|}
\hline \multirow[t]{2}{*}{ Species } & \multirow{2}{*}{$\begin{array}{l}\text { Species } \\
\text { code }\end{array}$} & \multirow[t]{2}{*}{$\mathrm{N}$} & \multirow{2}{*}{$\begin{array}{l}\text { Stomachs } \\
\text { with food }\end{array}$} & \multicolumn{3}{|c|}{ Length $(\mathrm{cm}) \longrightarrow$} & \multirow{2}{*}{$\begin{array}{c}\text { Mean mass } \\
(\mathrm{kg} \pm \mathrm{SD})\end{array}$} & \multirow{2}{*}{$\begin{array}{c}\text { Stomachs } \\
\text { with bait (\%) }\end{array}$} \\
\hline & & & & Min. & Max. & Mean $\pm \mathrm{SD}$ & & \\
\hline Alepisaurus ferox & ALEP & 144 & 120 & 20.2 & 153.0 & $92.6 \pm 33.8$ & $1.8 \pm 1.5$ & 13.9 \\
\hline Gempylus serpens & GEMP & 101 & 47 & 66.5 & 140.5 & $96.9 \pm 15.4$ & $1.3 \pm 0.7$ & 27.9 \\
\hline Lampris sp. big-eye & OPAH-B & 116 & 112 & 69.5 & 126.3 & $104.2 \pm 9.3$ & $41.9 \pm 9.7$ & 15.5 \\
\hline Lampris sp. small-eye & OPAH-S & 24 & 22 & 86.0 & 117.0 & $106.9 \pm 7.6$ & $46.8 \pm 9.8$ & 8.3 \\
\hline $\begin{array}{l}\text { Lepidocybium } \\
\text { flavobrunneum }\end{array}$ & ESCO & 45 & 4 & 27.0 & 111.0 & $62.4 \pm 17.6$ & $4.1 \pm 6.6$ & 2.2 \\
\hline
\end{tabular}

lected during 2009 to 2011 and collection was dependet upon the availability of trained fishery observers and cooperating boat captains. While aboard commercial fishing vessels operating in the central North Pacific Ocean, observers recorded species, fish length, sex (if known), and capture date. Approximate catch locations were made available in accordance with NOAA's Fisheries Operations Data Confidentiality Policy. The Hawaii-based longline fishery operates across a large portion of the Pacific Ocean, from the equator to $\sim 40^{\circ} \mathrm{N}$ and from $\sim 140^{\circ} \mathrm{W}$ to the International Date Line (see Choy \& Drazen 2013 for a map of general fishery effort). Specimens were collected from both shallow nighttime and deep daytime longline sets, which are typically set at $\sim 0$ to 100 and $\sim 100$ to $400 \mathrm{~m}$, respectively (Bigelow et al. 2006).

Most fish stomachs were extracted and frozen at sea until further analysis in the laboratory. Some specimens of snake mackerel, escolar, and lancetfish were frozen whole, after which stomachs were excised in the laboratory. Stomachs of both opah species were not commonly excised at sea, thus individuals were primarily sampled directly from local seafood wholesalers. While fish length and/or mass were available for these opah specimens, capture date and location were not. However, all opah were sampled from boats registered with the Hawaiibased longline fishery and are thus from the same biogeographic province as the other specimens included in this study.

Recent morphologic and genetic studies suggest that the tropical species of opah in the North Pacific currently known as Lampris guttatus is a complex of 2 species, which we refer to as 'small-eye' and 'bigeye' (J. Hyde pers. comm.; see also Hawn \& Collette 2012). To distinguish between the 2 opah species the 5 ' region of the mitochondrial cytochrome $c$ oxidase subunit 1 gene was sequenced following Ivanova et al. (2007). Using MEGA v4 (Tamura et al. 2007), sequences were compared by performing bootstrap resampling of neighbor joining trees (Kimura 2parameter model) with reference sequences from vouchered specimens of both opah species. Identification was determined when the queried sequence assigned with $>95 \%$ bootstrap probability to one group or the other.

In the laboratory, stomachs were defrosted whole in water for 1 to $2 \mathrm{~h}$ before processing. The whole weight of each unopened stomach was recorded, after which the stomach was cut open, the food bolus removed, and the weight of the cleaned stomach recorded. A qualitative estimate of stomach fullness was recorded based on the volumetric fraction of the stomach containing food: $0=$ empty or only containing bait, 1 = less than half full, $2=$ half full, $3=$ more than half full, $4=$ full. Prey items were sorted to the lowest identifiable taxon and separated by different states of digestion. The digestion state of the prey was classified similar to Olson \& Galván-Magaña (2002) and Choy (2008): 1 = intact with some or most skin on, 2 = relatively intact with some soft parts digested, $3=$ soft parts mostly or all digested, but skeletons or remains whole or nearly whole, $4=$ individuals not identifiable, mostly hard parts remaining (e.g. fish otoliths, cephalopod beaks, loose vertebrae, bones). Each taxon per digestive state was weighed to the nearest $0.1 \mathrm{~g}$, and the number(s) of individual prey types were recorded. If prey items were intact enough, length measurements were taken with calipers to the nearest $0.1 \mathrm{~mm}$ : mantle length (ML) for cephalopods, standard or total length (SL or TL) for fishes, TL or carapace length (CL) for crustaceans, and TL for gelatinous or other organisms.

For prey items in digestive states 1 or 2, the following keys were primarily used for taxonomic identification: Smith \& Heemstra (1986), Okiyama (1988), Nakamura \& Parin (1993), Vinogradov et al. (1996), Wrobel \& Mills (1998), Carpenter \& Niem (1999a,b, 
2001a,b), Nakabo (2002), Mundy (2005), and Randall (2007). Certain prey items were sent to specialized taxonomists for identification and/or verification (see 'Acknowledgements' section). Commercial bait items (species and sizes) were determined from communication with boat captains and bait suppliers; recently ingested specimens (digestion state $=1$ ) of the fish species Scomber japonicus and Cololabis saira were assumed to be bait and were excluded from the analysis. These 2 species were never found in a digestion state greater than 1 .

\section{Hard parts}

Fish otoliths and cephalopod beaks were rinsed with distilled water, collectively weighed to the nearest $0.01 \mathrm{~g}$, and enumerated. Otoliths were not identified, but beaks were identified with the help of expert taxonomists and the Tree of Life website (www.tolweb.org; Young et al. 2012). Upper and lower beak rostral lengths were measured to the nearest $0.1 \mathrm{~mm}$ using an ocular micrometer. Cephalopod species were enumerated based on the lowest number of upper or lower beaks of comparable rostral lengths, which is a conservative minimum count.

Anthropogenic debris was also included as hard parts because of the likelihood of hard plastics and other non-biological material accumulating in the stomachs of these predators. Quantitative summaries and further discussion of anthropogenic debris ingestion are available in Choy \& Drazen (2013).

\section{Data analysis}

For each prey taxon, 3 main diet indices were calculated: gravimetric importance as proportions of total prey weights $(\% \mathrm{~W})$, numerical importance as proportions of total counts $(\% \mathrm{~N})$, and frequency of occurrence as proportions of predator stomachs containing said prey item $(\% \mathrm{~F})$. \%F was calculated based on the number of predator stomachs with contents. To facilitate analysis and ecological interpretation we also grouped prey taxa by family and by functional group based on known ecological traits. Cephalopod prey identified from beaks were not included in overall $\% \mathrm{~N}, \% \mathrm{~W}$, and $\% \mathrm{~F}$ calculations because of the potentially long time windows over which these hard parts accumulate in stomachs.

Cumulative prey curves were used to assess whether or not stomachs sampled for each species were adequate enough to describe diet diversity and breadth. Curves plotted numbers of prey taxa identified against cumulative numbers of stomachs sampled; prey data were sampled without replacement and 500 iterations were used to generate average numbers of prey taxa with varying stomach sample sizes.

As fishes and cephalopods formed the most substantial gravimetric component of the diets of all predators, ecological depth categories were assigned to these 2 groups of prey items using depth of capture values from the literature. Depth categories for the fishes mirror those used in Choy et al. (2009), with the exception of the general 'mesopelagic' category. This category was assigned to both prey fish and cephalopods lacking detailed depth information but generally known to inhabit waters below $\sim 200 \mathrm{~m}$ (i.e. based on average day- and night-time depths). To elucidate broad foraging behaviors, prey were grouped into 12 functional groups based on known natural history and ecological information (Table S1 in the Supplement at www.int-res.com/articles/suppl/ m492p169_supp.pdf). To present a big picture view of predator diet, both anthropogenic debris and cephalopod individuals identified from hard parts were included in functional group analyses.

Modified Costello diagrams (Costello 1990) plotting $\% \mathrm{~W}$ against $\% \mathrm{~N}$ were used to identify important prey items contributing to differences in diets and to evaluate general feeding strategies. Diagrams include the 5 most important prey items by \%W and $\% \mathrm{~N}$, excluding unidentified prey and anthropogenic debris. Overall diets were compared with one another using a percent similarity index (PSI or Schoener's similarity index; Schoener 1970, Hurlbert 1978), with prey identifications at both the family and most specific levels, including cephalopods identified from hard parts. Predators were considered to have similar diets to one another if PSI values were 60 or greater (after Wallace \& Ramsey 1983). Interspecific size-based differences in diet were examined for bigeye opah and lancetfish, the only 2 species where sample sizes were sufficiently spread across a broad range of sizes (as forklengths). Individuals were broken into 3 distinct size classes, allowing for even sample distributions across size classes as much as possible, and diets for the different size classes were compared using PSI within a species. For this analysis both gravimetric and numerical contributions of prey were examined at the most specific taxonomic level available, including cephalopods identified from hard parts. All data analysis and statistics were performed in R version 2.15.1 (R Development Core Team 2012). 


\section{RESULTS}

\section{General diet composition}

A total of 430 stomachs of lancetfish, snake mackerel, escolar, big-eye opah, and small-eye opah were obtained, 305 of which contained food (Table 1). Seasonal and annual distributions of samples are shown in Table S2 in the Supplement; uneven distributions between years and seasons prevented robust temporal comparisons. From these 305 stomachs, 189 different prey types of varying taxonomic resolution were identified, among which a total of 85 fish, mollusk, crustacean, and gelatinous animal families were identified (Table 2). Of the 189 prey types, 78 occurred in the stomachs of at least 2 of the predator species, and only a small number appeared in stomachs of 3 or all of the predator species.

Cumulative prey curves indicated that sample sizes for all 4 species (escolar not presented) were probably not adequate enough to fully describe general diet diversity as none of the curves approach an asymptote (Fig. 1). Opportunistic sampling over multiple years, seasons, and areas probably limited the ability of our diet descriptions to fully describe diet breadth for any of these species and evaluate the potential importance of time and/or space to diet.

There was a high incidence of empty stomachs for snake mackerel (53\%) and escolar (91\%) (Table 1). The potential influences of general location, fishery set type, time of haul, and fish size on stomach fullness were examined, but no clear relationships were observed. The majority of snake mackerel were sampled from deep-set longlines put out during early morning hours and hauled up in late afternoon and early evening hours, but stomach fullness was evenly

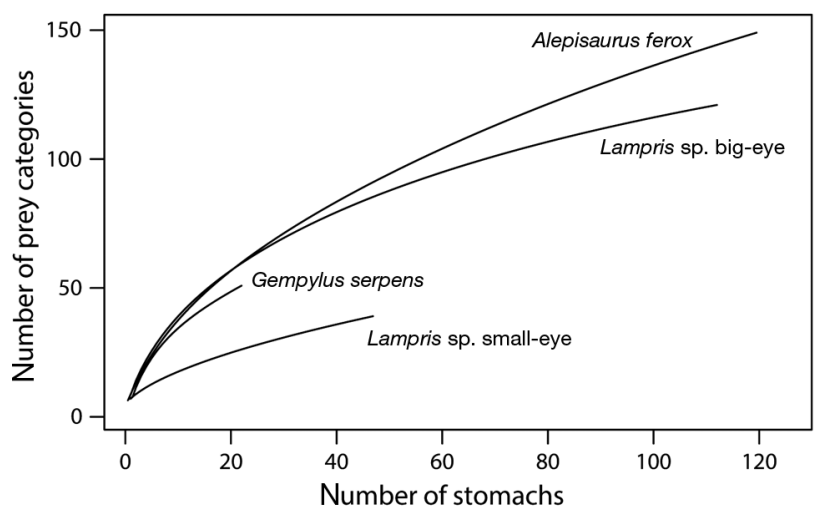

Fig. 1. Cumulative prey curves for big-eye opah (Lampris sp. big-eye), small-eye opah (Lampris sp. small-eye), snake mackerel Gempylus serpens, and lancetfish Alepisaurus ferox distributed between fish sampled on deep and shallow sets. Escolar were sampled evenly on deep and shallow sets; the 4 specimens containing food all came from deep sets. Numerous whole fish specimens of snake mackerel and escolar were also examined for signs of stomach eversion (e.g. food items lodged in the esophagus or gills), but none were noted. Owing to the low sample size of escolars containing food, we have omitted this species from all statistical comparisons; data for the individuals containing food are presented in Table 3.

Prey types were assigned to 5 broad categories: crustaceans, fishes, gelatinous organisms, invertebrates, and mollusks (Table 2). Anthropogenic debris, much of which was plastic, also made up substantial portions of the stomach contents of some of the predators and contributions were tabulated in terms of $\% \mathrm{~N}, \% \mathrm{~W}$, and $\% \mathrm{~F}$. By weight, all predators fed dominantly on fishes (range: $58.3 \% \mathrm{~W}$ for small-eye opah to $66.9 \% \mathrm{~W}$ for big-eye opah), and secondarily on mollusks (range: $5.6 \% \mathrm{~W}$ for small-eye opah to $37.2 \% \mathrm{~W}$ for snake mackerel). Fishes were most numerically important in the diets of snake mackerel $(66.7 \% \mathrm{~N})$ and big-eye opah $(26.3 \% \mathrm{~N})$. Lancetfish was the only predator that fed to a substantial gravimetric degree on crustaceans $(9.4 \%)$, whereas crustaceans were practically absent from the diet of snake mackerel $(<1 \% \mathrm{~W}, 2.1 \% \mathrm{~N})$. Crustaceans were the most numerically important broad prey category for lancetfish $(42.7 \% \mathrm{~N})$ and both opah also consumed numerous crustaceans (32.9 and $27.44 \% \mathrm{~N}$ for big-eye and small-eye, respectively). Gelatinous prey contributions were minor to the diets of big-eye opah $(1.6 \% \mathrm{~W}, 2.5 \% \mathrm{~N})$, lancetfish $(3.5 \% \mathrm{~W}, 15.4 \% \mathrm{~N})$, and snake mackerel $(0 \% \mathrm{~N}, 0 \% \mathrm{~W})$; the exception was small-eye opah $(21.3 \% \mathrm{~N}, 9.7 \% \mathrm{~W})$, which fed on unidentified pyrosomes. Mollusks were a numerically dominant component of the diets of all predators (range: $9.2 \% \mathrm{~N}$ for small-eye to $29.9 \% \mathrm{~N}$ for bigeye opah), with the majority of the individuals identified from cephalopod beak remains.

\section{Cephalopod prey differences}

Over 2000 cephalopod beaks were identified (Table 2), and a family level analysis combining individuals identified from beaks and soft tissue indicated differences between cephalopod assemblages consumed by the 4 predators in terms of numbers of individuals (Fig. 2C). As cephalopod prey identified from tissue and hard parts integrate different time scales of feeding; cephalopod prey 
Table 2. Abridged prey tables for big-eye opah (OPAH-B), small-eye opah (OPAH-S), lancetfish (ALEP), and snake mackerel (GEMP) for prey items contributing greater than $1 \%$ by weight $(\% \mathrm{~W})$ or number $(\% \mathrm{~N})$ to the diets of any of these 4 predators. Included for each prey item are the percentage of the total number of prey $(\% \mathrm{~N})$, the percentage of the total weight of the prey $(\% \mathrm{~W})$, and the percent frequency of occurrence $(\% \mathrm{~F})$ for each predator species. $\% \mathrm{~N}$ and $\% \mathrm{~W}$ for main prey categories (crustaceans, fishes, gelatinous and invertebrates, anthropogenic debris) are summarized in bold for each predator. For mollusks, (B) indicates taxa identified from beaks; in brackets are the conservative numbers of individuals identified from beaks. Note that family level (bold text) \% N and \% W values are not family-level subtotals but specific prey items identified only to family level. A complete prey table (including functional group assignments) is provided in Table S1 in the Supplement at www.int-res.com/articles/suppl/m492p169_supp.pdf

\begin{tabular}{|c|c|c|c|c|c|c|c|c|c|c|c|c|}
\hline & \multicolumn{3}{|c|}{ OPAH-B } & \multicolumn{3}{|c|}{ ALEP } & \multicolumn{3}{|c|}{ OPAH-S } & \multicolumn{3}{|c|}{ GEMP } \\
\hline & $\% \mathrm{~N}$ & $\% \mathrm{~W}$ & $\% \mathrm{~F}$ & $\% \mathrm{~N}$ & $\% \mathrm{~W}$ & $\% \mathrm{~F}$ & $\% \mathrm{~N}$ & $\% \mathrm{~W}$ & $\% \mathrm{~F}$ & $\% \mathrm{~N}$ & $\% \mathrm{~W}$ & $\% \mathrm{~F}$ \\
\hline CRUSTACEANS & 32.95 & 4.53 & - & 42.67 & 9.24 & - & 27.44 & 3.64 & - & 2.08 & 0.09 & - \\
\hline Cyphocarididae & 1.71 & 0.03 & 3.57 & 0.26 & 0.02 & 0.83 & & & & & & \\
\hline Euphausiacea & 7.05 & 1.91 & 4.46 & & & & & & & & & \\
\hline Lycaeidae - Brachyscelus sp. & 0.76 & 0.02 & 2.68 & 0.06 & 0.00 & 0.83 & & & & & & \\
\hline $\begin{array}{l}\text { Oplophoridae - Oplophorus } \\
\text { gracilirostris }\end{array}$ & & & & & & & & & & 2.08 & 0.09 & 2.13 \\
\hline Penaeidae - Funchalia taaningi & 0.19 & 0.06 & 0.89 & & & & 12.80 & 1.17 & 4.55 & & & \\
\hline Phronimidae - Phronima sedentaria & & & & 4.41 & 1.52 & 18.33 & & & & & & \\
\hline Phronima sp. & 1.33 & 0.04 & 2.68 & 1.79 & 0.54 & 6.67 & 2.44 & 0.12 & 13.64 & & & \\
\hline Phrosinidae - Phrosina semilunata & 0.76 & 0.02 & 1.79 & 21.5 & 4.12 & 47.50 & & 0.05 & 4.55 & & & \\
\hline Platyscelidae - Platyscelus armatus & 0.38 & 0.01 & 1.79 & 2.88 & 0.54 & 15.83 & & & & & & \\
\hline Platyscelus ovoides & 4.00 & 0.33 & 5.36 & 5.63 & 1.28 & 11.67 & 1.83 & 0.90 & 9.09 & & & \\
\hline Platyscelus sp. & 7.24 & 0.60 & 26.79 & 0.32 & 0.04 & 2.50 & 4.88 & 1.05 & 27.27 & & & \\
\hline Hyperiidea & 2.86 & 0.07 & 5.36 & 0.77 & 0.13 & 4.17 & 2.44 & 0.19 & 13.61 & & & \\
\hline Shrimp (unidentified) & 0.00 & 0.03 & 1.79 & 1.41 & 0.34 & 8.33 & 0.00 & 0.01 & 4.55 & & & \\
\hline Unidentified crustacea & 4.19 & 1.21 & 19.64 & 0.26 & 0.06 & 2.50 & 2.44 & 0.10 & 22.73 & & & \\
\hline FISH & 26.29 & 66.86 & - & 25.40 & 63.66 & - & 12.20 & 58.31 & - & 66.67 & 62.37 & - \\
\hline Alepisauridae - Alepisaurus ferox & 2.29 & 20.08 & 6.25 & 1.47 & 23.96 & 15.00 & 1.22 & 4.78 & 4.55 & & & \\
\hline Alepisaurus sp. & 1.14 & 10.24 & 4.46 & 1.22 & 3.34 & 6.67 & & & & & & \\
\hline $\begin{array}{l}\text { Anoplogasteridae - Anoplogaster } \\
\text { cornuta }\end{array}$ & & & & 1.41 & 4.54 & 4.17 & & & & & & \\
\hline Bramidae - Brama myersi & & & & & & & & & & 2.08 & 0.78 & 2.13 \\
\hline Pteraclis aesticola & & & & 0.26 & 2.48 & 3.33 & 2.44 & 42.36 & 9.09 & & & \\
\hline Exocoetidae & & & & & & & & & & 4.17 & 4.14 & 4.26 \\
\hline Hirundichthys albimaculatus & & & & & & & & & & 2.08 & 1.88 & 2.13 \\
\hline Gempylidae & & & & & & & & & & 2.08 & 4.11 & 2.13 \\
\hline Diplospinus multistriatus & 0.38 & 0.05 & 0.89 & 0.58 & 0.81 & 5.00 & & & & 2.08 & 0.06 & 2.13 \\
\hline Gempylus serpens & & & & & & & & & & 6.25 & 12.37 & 4.26 \\
\hline Lepidocybium flavobrunneum & & & & & & & & & & 2.08 & 2.21 & 2.13 \\
\hline Melanocetidae & & & & 0.06 & 0.02 & 0.83 & & & & & & \\
\hline Molidae - Ranzania laevis & & & & 0.06 & 2.10 & 0.83 & & & & 18.75 & 32.99 & 14.89 \\
\hline Myctophidae & 2.48 & 0.66 & 4.46 & 0.32 & 0.00 & 0.83 & & & & & & \\
\hline Omosudidae - Omosudis lowei & 0.76 & 1.85 & 3.57 & 0.45 & 3.43 & 5.00 & 0.61 & 0.01 & 4.55 & & & \\
\hline Paralepididae & 3.05 & 3.66 & 2.68 & 0.13 & 0.07 & 1.67 & 0.61 & 0.89 & 4.55 & 2.08 & 0.51 & 2.13 \\
\hline $\begin{array}{l}\text { Scopelarchidae - Scopelarchus } \\
\text { michaelsarsi }\end{array}$ & 1.33 & 2.75 & 1.79 & 0.06 & 0.15 & 0.83 & 0.61 & 0.20 & 4.55 & & & \\
\hline Sternoptychidae & 1.52 & 0.65 & 2.68 & 0.26 & 0.19 & 1.67 & & & & & & \\
\hline Argyropelecus aculeatus & & & & 0.19 & 1.31 & 2.50 & & & & & & \\
\hline Sternoptyx diaphana & & & & 3.58 & 4.46 & 10.00 & & & & & & \\
\hline Sternoptyx pseudobscura & 0.19 & 0.08 & 0.89 & 5.50 & 8.14 & 19.17 & & & & & & \\
\hline Sternoptyx sp. & 2.10 & 1.03 & 4.46 & 3.45 & 3.50 & 10.83 & & & & & & \\
\hline Trichiuridae/Gempylidae & 1.14 & 0.02 & 2.69 & 0.06 & 0.03 & 0.83 & & & & 2.08 & 0.00 & 2.13 \\
\hline Unidentified fish & 6.29 & 24.41 & 74.11 & 1.60 & 1.20 & 20.00 & 6.71 & 10.07 & 90.91 & 22.92 & 3.66 & 31.91 \\
\hline $\begin{array}{l}\text { GELATINOUS AND OTHER } \\
\text { INVERTEBRATES }\end{array}$ & 2.48 & 1.59 & - & 15.36 & 3.47 & - & 21.34 & 9.74 & - & - & - & - \\
\hline Alciopidae - Vanadis sp. & & & & 9.66 & 1.33 & 23.33 & & & & & & \\
\hline Pyrosomidae & 0.57 & 0.92 & 2.68 & 0.13 & 0.10 & 1.67 & 15.24 & 8.63 & 27.27 & & & \\
\hline Salpidae & 0.95 & 0.11 & 3.57 & 5.18 & 2.01 & 20.83 & 5.49 & 1.11 & 13.64 & & & \\
\hline
\end{tabular}


Table 2 (continued)

\begin{tabular}{|c|c|c|c|c|c|c|c|c|c|c|c|c|}
\hline & \multicolumn{3}{|c|}{ ОРАН-В } & \multicolumn{3}{|c|}{ ALEP } & \multicolumn{3}{|c|}{ OPAH-S } & \multicolumn{3}{|c|}{ GEMP } \\
\hline & $\% \mathrm{~N}$ & $\% \mathrm{~W}$ & $\% \mathrm{~F}$ & $\% \mathrm{~N}$ & $\% \mathrm{~W}$ & $\% \mathrm{~F}$ & $\% \mathrm{~N}$ & $\% \mathrm{~W}$ & $\% \mathrm{~F}$ & $\% \mathrm{~N}$ & $\% \mathrm{~W}$ & $\% \mathrm{~F}$ \\
\hline MOLLUSKS & 21.90 & 21.99 & - & 10.88 & 14.75 & - & 9.15 & 5.55 & - & 29.17 & 37.17 & - \\
\hline $\begin{array}{l}\text { Ancistrocheiridae - Ancistrocheirus } \\
\text { lesueurii }\end{array}$ & & & & 0.19 & 0.05 & 2.50 & & & & 2.08 & 9.72 & 2.13 \\
\hline Argonautidae - Argonauta argo & & & & 1.02 & 3.17 & 8.33 & & & & & & \\
\hline A. $\operatorname{argo}(\mathrm{B})$ & [3] & & 2.68 & [1] & & 0.83 & [11] & & 27.27 & [1] & & 2.13 \\
\hline Bolitaenidae - Japetella diaphana & 1.90 & 0.44 & 5.36 & 0.70 & 0.88 & 7.50 & 1.22 & 0.46 & 4.55 & & & \\
\hline Histioteuthidae & & & & & & & & & & 4.17 & 1.35 & 4.26 \\
\hline Stigmatoteuthis hoylei & 0.19 & 6.89 & 0.89 & & & & & & & 2.08 & 2.20 & 2.13 \\
\hline $\begin{array}{l}\text { Ommastrephidae - Hyaloteuthis } \\
\text { pelagica }\end{array}$ & 0.38 & 0.04 & 0.89 & 1.28 & 3.47 & 10.83 & & & & & & \\
\hline Ommastrephes bartramii & & & & & & & & & & 2.08 & 1.46 & 2.13 \\
\hline Sthenoteuthis oualaniensis & & & & 0.32 & 0.01 & 1.67 & & & & 12.50 & 14.24 & 10.64 \\
\hline Onychoteuthidae - Onykia sp. A & & & & & & & & & & 2.08 & 3.31 & 2.13 \\
\hline Walvisteuthis youngorum & 3.24 & 7.32 & 9.82 & 0.06 & 0.85 & 0.83 & 3.66 & 0.98 & 9.09 & & & \\
\hline Thecosomata & 0.38 & 0.00 & 1.79 & 1.41 & 0.09 & 10.00 & & & & & & \\
\hline ANTHROPOGENIC DEBRIS & 16.38 & 5.03 & 40.83 & 5.69 & 8.69 & 38.39 & 29.88 & 22.76 & 63.64 & 2.08 & $\mathbf{0}$ & 2.13 \\
\hline Totals & 525 & 2920 & - & 1563 & 2444 & - & 164 & 906 & - & 48 & 1911 & - \\
\hline
\end{tabular}

Table 3. Summary of prey found in 4 Lepidocybium flavobrunneum individuals as prey numbers and weights. A total of $45 \mathrm{~L}$. flavobrunneum individuals were examined, 4 of which contained prey

\begin{tabular}{|lcc|}
\hline Prey identification & Number(s) & Weight(s) (g) \\
\hline Cephalopoda & & \\
$\quad$ - Sthenoteuthis oualaniensis & 2 & 47.31 \\
Crustacea - Aristaeidae & 2 & 3.06 \\
Teleostei - Unidentified fish & 1 & 4.68 \\
Unidentified otoliths & 3 & 0.01 \\
\hline
\end{tabular}

differences are presented specific to either tissue or hard-part remains.

Compared with fish and crustacean prey, cephalopod prey identified from soft tissue remains were relatively few. In terms of both $\% \mathrm{~N}$ and $\% \mathrm{~W}$, these cephalopod prey were distributed quite evenly across different family and species groups. The exceptions were Ancistrocheirus lesueurii $(9.7 \% \mathrm{~W}$ for snake mackerel, for overall diet), Sthenoteuthis oualaniensis $(12.5 \% \mathrm{~N}$ and $14.2 \% \mathrm{~W}$ for snake mackerel), and Walvisteuthis youngorum (7.3\%W for big-eye opah) (Table 2).

In terms of cephalopod prey diversity, snake mackerel consumed the narrowest overall range of cephalopods ( 7 families from beaks and 4 from tissue), while lancetfish consumed the most diverse range of cephalopods (17 families from tissue and 14 from beaks). Despite big-eye and small-eye opah consuming the largest absolute numbers of cephalopod individuals (as beaks), the onychoteuthid squid Walvisteuthis youngorum numerically dominated the diets of the 2 opah species (Table S3 in the Supplement). In terms of cephalopod prey diversity identified from beak remains, big-eye opah fed more broadly (22 prey families) than small-eye opah (12 prey families). These differences in cephalopod prey diversity are probably related to uneven sample sizes for the 2 opah species, as indicated by results from the cumulative prey curves (Fig. 1).

Muscular ommastrephid and onychoteuthid squids were consumed in large numbers (from beaks) by all predators, the exception being lancetfish (no ommastrephids and the smallest number of onychoteuthids). Only lancetfish consumed deeper-dwelling, slowmoving cranchiid squids in substantial numbers $(24.1 \% \mathrm{~N}$ of beaks). Bolitaenids from beaks were dominant only in the diets of big-eye $(22.4 \% \mathrm{~N})$ and small-eye $(25.3 \% \mathrm{~N})$ opah, especially the deepdwelling species Japetella diaphana.

Cephalopods identified from hard parts far outnumbered those identified from soft tissue, thus we analyzed absolute beak rostral lengths to look for differences in size-based predation. Although beak-tobody-length size relationships are available for some species (e.g. Clarke 1986), they are missing for the majority of the central North Pacific species. Beak-toML conversions were available for squids from the family Ommastrephidae; snake mackerel consumed significantly larger ommastrephids (mean \pm SD ML $128 \pm 25 \mathrm{~mm}$ ) than both big-eye (mean ML $92 \pm$ $45 \mathrm{~mm}$ ) and small-eye opah (mean ML $105 \pm 28 \mathrm{~mm}$ ) ( $t$-test, $\mathrm{p}=0.05$ and $\mathrm{p}=0.04$, respectively). Beak-toML ratios are known to vary interspecifically (Clarke 1986), and thus limited information prevented robust 
A OPAH-B \%N

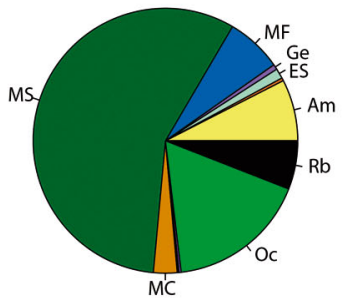

B OPAH-B \%W

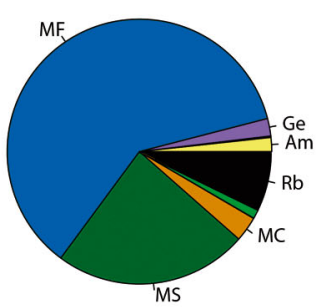

C OPAH-B

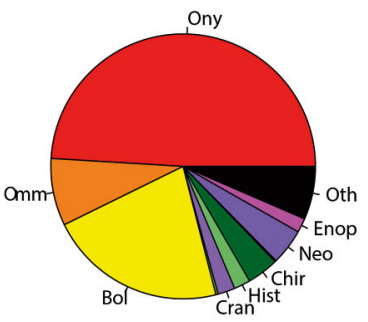

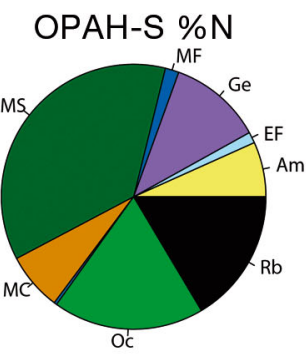

OPAH-S \%W

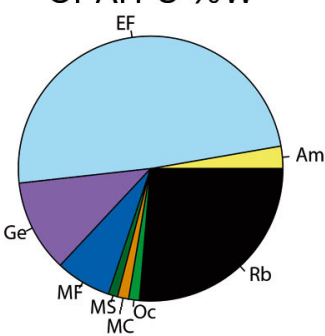

OPAH-S

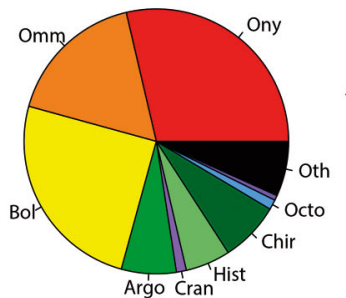

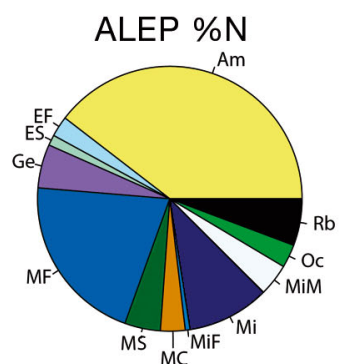

ALEP \%W

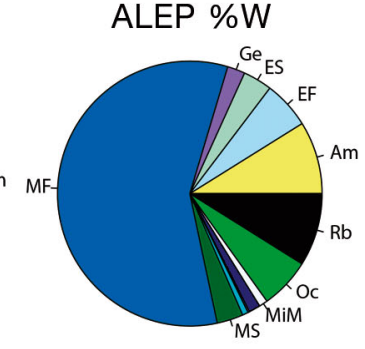

ALEP

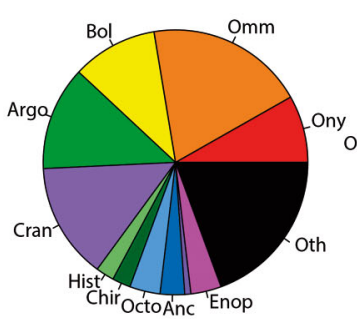

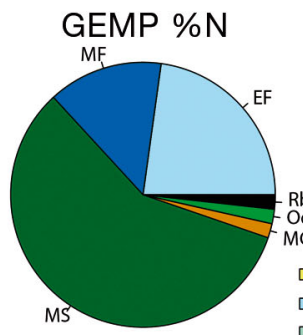

Amphipods

$\square$ Epipelagic fishes

$\square$ Epipelagic squids

$\square$ Gelatinous

- Mesopelagic fishes

$\square$ Mesopelagic squids

$\square$ Micronekton crustaceans

- Miscellaneous fishes

- Miscellaneous others

$\square$ Miscellaneous molluscs

$\square$ Octopods

- Rubbish

Fig. 2. (A) Numeric $(\% \mathrm{~N})$ diet compositions of lancetfish (ALEP), snake mackerel (GEMP), big-eye opah (OPAH-B), and smalleye opah (OPAH-S), segregated into select functional groups. The functional group abbreviations are as follows: Am = amphipods, EF = epipelagic fishes, ES = epipelagic squids, Ge = gelatinous, MF = mesopelagic fishes, MS = mesopelagic squids, $\mathrm{MC}=$ micronekton crustaceans, $\mathrm{MiF}=$ miscellaneous fishes, $\mathrm{Mi}=$ miscellaneous others, $\mathrm{MiM}=$ miscellaneous mollusks, $\mathrm{Oc}=$ octopods, $\mathrm{Rb}=$ rubbish. (B) Gravimetric (\%W) diet compositions of predators, segregated into select functional groups. (C) Cephalopod prey numerical composition $(\% \mathrm{~N})$ of predators, segregated by most important families. Numerical composition includes cephalopod individuals identified from both soft tissue and hard parts

comparisons of cephalopod prey sizes consumed by the 4 predators, particularly lancetfish, which preyed on a different cephalopod community than the other predators. Snake mackerel, small-eye opah, and bigeye opah consumed cephalopod prey of similar familial compositions and preyed on cephalopods with an even distribution of beak rostral lengths, most of which were less than $5 \mathrm{~mm}$.

\section{Prey functional groups and depth differences}

The 4 predators exploited different functional groups of prey in terms of both numbers and weights (Fig. 2A,B). Lancetfish fed numerically and gravimetrically most diversely across the 12 functional groups. Lancetfish clearly exploited mesopelagic fishes $(20.8 \% \mathrm{~N}, 58 \% \mathrm{~W})$ as well as hyperiid am- phipods, which were consumed in large numbers $(39.6 \% \mathrm{~N})$ and represented the second highest gravimetric functional group $(8.9 \% \mathrm{~W})$.

Similarities also existed in terms exploited functional groups. For example, all predators except lancetfish fed to a dominant numerical degree on mesopelagic squids (Fig. 2A,B). When cephalopod prey identified from hard parts were excluded, mesopelagic squids lost their dominance, except in the diets of snake mackerel $(36.1 \% \mathrm{~N}, 37.2 \% \mathrm{~W})$ and bigeye opah $(8.1 \% \mathrm{~N}, 26.3 \% \mathrm{~W})$. Numerically, the 2 opah species had similar profiles of exploited functional groups, but there were stark gravimetric differences that suggest differences in feeding depths. Big-eye opah fed dominantly on mesopelagic fishes by weight (e.g. paralepidids and lancetfish; Fig. 2B), while Pteraclis aesticola, a large epipelagic bramid species, constituted almost half of the wet prey bio- 
mass for small-eye opah. Snake mackerel displayed the narrowest selection of functional prey groups by weight, feeding almost exclusively on epipelagic fishes $(42.3 \% \mathrm{~W})$, mesopelagic squids $(37.2 \% \mathrm{~W})$, and mesopelagic fishes $(20.5 \% \mathrm{~W})$.

\section{Size-based intraspecific diet comparisons}

Lancetfish diet was more similar (i.e. higher PSI values) across small (40 to $80 \mathrm{~cm}$ ), medium (81 to $120 \mathrm{~cm})$, and large (121 to $160 \mathrm{~cm}$ ) size classes in terms of prey numbers than prey weights (Table 4). The same was true for the diets of big-eye opah for small $(60$ to $90 \mathrm{~cm})$, medium (91 to $110 \mathrm{~cm})$, and large $(111$ to $130 \mathrm{~cm}$ ) size classes. In terms of \%W, smaller lancetfish $(40$ to $80 \mathrm{~cm}$ ) fed most on the squid Hyaloteuthis pelagica and the hyperiid amphipod Phrosina semilunata, while also cannibalizing small juveniles. Cannibalism was however most evident in large lancetfish (121 to $160 \mathrm{~cm}$ ), where $40 \%$ of their diet was smaller lancetfish (by \%W). Fishes also comprised the gravimetric majority of the diets of large lancetfish, whereas smaller size classes fed on cephalopods and crustaceans in addition to fishes.

The largest intraspecific differences in diets with size were observed for big-eye opah, in terms of gravimetric prey contributions, where large (111 to $130 \mathrm{~cm}$ ) big-eye opah diets were most different from small (60 to $90 \mathrm{~cm}$ ) big-eye opah diets (PSI 6.4; Table 4). Larger big-eye opah fed primarily on a suite of micronekton fishes (lancetfish, sternoptychids, scopelarchids, and omosudids) and on the mesopela-

Table 4. Percent similarity index (PSI) values for different size classes of (A) big-eye opah, and (B) lancetfish. PSI values are given in terms of prey numbers (below diagonal) and weights (above diagonal) at the most specific taxonomic prey level, and intraspecific size classes are based on fish size as forklength in centimeters. Prey items do not include unidentified or anthropogenic rubbish items. ${ }^{*}$ Diet similarities (cf. Wallace \& Ramsey 1983)

\begin{tabular}{|lccc|}
\hline Size class $(\mathrm{cm})$ & \multicolumn{3}{c|}{ Size class $(\mathrm{cm})$} \\
\hline (A) Big-eye opah & $\mathbf{6 0 - 9 0}$ & $\mathbf{9 1 - 1 1 0}$ & $\mathbf{1 1 1 - 1 3 0}$ \\
\hline $60-90$ & - & 17 & 6 \\
$91-110$ & $62^{*}$ & - & 35 \\
$111-130$ & 55 & $68^{*}$ & - \\
(B) Lancetfish & $\mathbf{4 0 - 8 0}$ & $\mathbf{8 1 - 1 2 0}$ & $\mathbf{1 2 1 - 1 6 0}$ \\
\hline $40-80$ & - & 33 & 33 \\
$81-120$ & 40 & - & 25 \\
$121-160$ & 51 & 53 & - \\
\hline
\end{tabular}

gic squid Walvisteuthis youngorum. Smaller size classes $(60$ to $90 \mathrm{~cm})$ on the other hand fed on a mostly different suite of mesopelagic micronekton fishes (paralepidids, chiasmodontids, myctophids, and sternoptychids) and on amphipods from the families Platyscelidae and Cyphocarididae. Size-based diet differences were not as evident in terms of prey numbers, as 2 cephalopods ( $W$. youngorum and Japetella diaphana) identified from beaks numerically dominated the diets of all big-eye opah size classes.

\section{Interspecific diet comparisons}

The overall diets of lancetfish, snake mackerel, big-eye opah, and small-eye opah were compared at the most specific level and at the family level in terms of prey numbers and weights, and were found to be very different as evidenced by very low and non-significant PSI values (Table 5). The highest similarities (i.e. highest PSI values) were between big-eye opah and small-eye opah (PSI of 57 at family level for numbers) and between big-eye opah and lancetfish (PSI of 44 at family level for weights). Costello diagrams illustrating the numeric and gravimetric importance of individual prey items indicate which prey items contributed the most to dissimilar diets among the predators (Fig. 3).

\section{DISCUSSION}

The 5 species of mesopelagic predatory fishes sampled from the NPSG in this study are broad consumers of epipelagic and mesopelagic micronekton fishes, cephalopods, crustaceans, and gelatinous organisms. Our data suggest that snake mackerel, lancetfish, big-eye opah, and small-eye opah each have unique feeding habits.

Table 5. Percent similarity index (PSI) values between 4 species of predators: big-eye (OPAH-B) and small-eye opah (OPAH-S), lancetfish (ALEP), and snake mackerel (GEMP). PSI values are given in terms of prey numbers (below diagonal) and weights (above diagonal) at most specific prey level, and at the family level (numbers in square brackets). Prey items do not include unidentified or anthropogenic rubbish items

\begin{tabular}{|lcccc|}
\hline & GEMP & ALEP & OPAH-B & OPAH-S \\
\hline GEMP & - & $2[7]$ & $3[8]$ & $<1[3]$ \\
ALEP & $3[8]$ & - & $36[44]$ & $20[18]$ \\
OPAH-B & $3[27]$ & $16[19]$ & - & $15[15]$ \\
OPAH-S & $12[36]$ & $15[19]$ & $48[57]$ & - \\
\hline
\end{tabular}



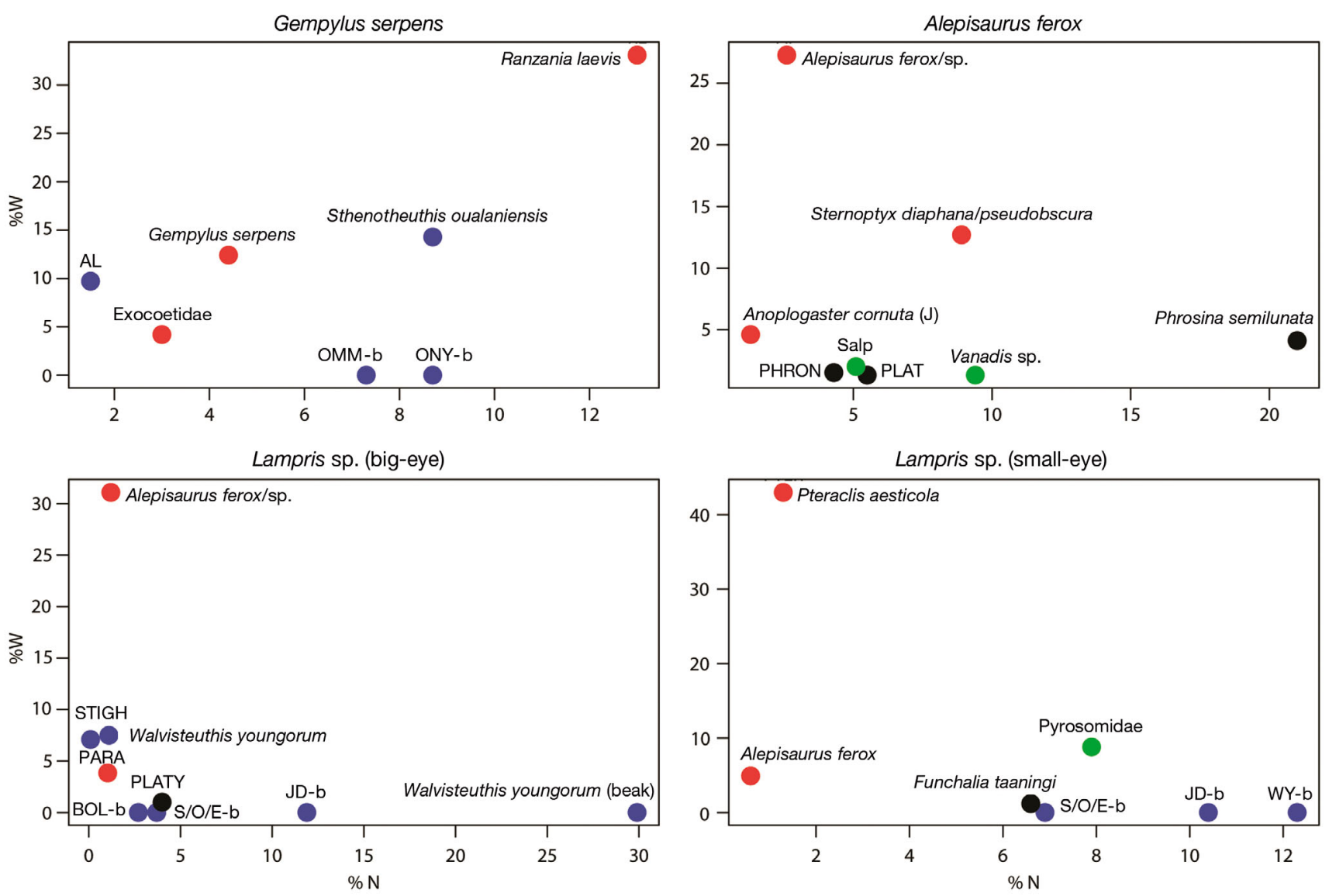

Fig. 3. Modified Costello diagrams showing the most important prey items in terms of prey biomass (\%W) and numerical importance $(\% \mathrm{~N})$ for all specimens of snake mackerel, lancetfish, big-eye opah, and small-eye opah. Different colored circles represent broad prey types $($ red $=$ fishes, blue $=$ cephalopods, black $=$ crustaceans, green $=$ invertebrates and gelatinous). Prey item abbreviations are as follows: $\mathrm{AL}=$ Ancistrocheirus lesueurii, BOL-b = Bolitaenidae (beak), JD-b = Japetella diaphana (beak), OMM-b = Ommastrephidae (beak), ONY-b = Onychoteuthis sp. (beak), PARA = Paralepididae, PHRON = Phronima sedentaria, $\mathrm{PLAT}=$ Platyscelus ovoides, PLATY = Platyscelus armatus/ovoides/sp., $\mathrm{S} / \mathrm{O} / \mathrm{E}-\mathrm{b}=$ Sthenoteuthis/Ommastrephes/ Eucleoteuthis (beak), STIGH = Stigmatoteuthis hoylei, WY-b = Walvisteuthis youngorum (beak)

\section{Diets of big-eye and small-eye opah}

Compared to the southern opah Lampris immaculatus, which appears to have a rather narrow diet range, NPSG big-eye and small-eye opah have very broad, diverse diets, feeding on numerous species of micronekton across many animal groups (fishes, cephalopods, crustaceans, gelatinous animals). In contrast, Jackson et al. (2000b) reported that 3 mesopelagic prey items (a myctophid and 2 squid species) encompassed $>90 \%$ of the prey biomass in the diet of the southern opah. One of these squid species, Moroteuthis ingens, inhabits deep mesopelagic Southern Ocean waters of $\sim 650$ to $700 \mathrm{~m}$, to as deep as $1400 \mathrm{~m}$ (Jackson et al. 2000a). The dominance of deep-dwelling (and migratory) fish and squid prey suggests that this species utilizes a large portion of the mesopelagic habitat in a fashion similar to Lampris spp. in the central North Pacific.
Differences in the consumption of numbers and weights of prey from distinct functional groups suggest that big-eye opah may feed on deeper-dwelling micronekton organisms than small-eye opah. For example, big-eye opah did not feed on any epipelagic fishes (despite larger numbers of stomachs sampled-116 big-eye vs. 24 small-eye), while epipelagic fishes dominated gravimetric prey contributions to the small-eye opah diet. Prey cephalopod species between the 2 opah species were highly similar (Table S3 in the Supplement), but big-eye opah did consume much higher numbers of deep-dwelling non-migratory cephalopods (e.g. Histioteuthis sp., Japetella diaphana; see Young 1978) more frequently than small-eye opah. Slight differences in morphology may also support the idea that big-eye opah forage deeper than small-eye opah. As their name implies, eye diameter is slightly larger in big- 
eye opah, perhaps as an adaptation to lower light levels. Torso colors are also different, with small-eye opah having a light grey torso and big-eye opah having a more pinkish-metallic torso, better adapted for camouflage in the mesopelagic (J. Hyde, K. Underkoffler, B. Mundy pers. comm.). Though our results are suggestive, further examination of smalleye opah diet is necessary to ensure that differences in diet from big-eye opah are not an artifact of skewed sample sizes.

Of the 5 predators, the 2 opah species consumed the most anthropogenic debris as numbers and weights (see Table 2). Details of this unusually high debris consumption are discussed separately (Choy \& Drazen 2013), but it is of relevance to note that Jackson et al. (2000b) also found that a large proportion of the Lampris immaculatus specimens examined had ingested a variety of plastic (14\%). White or clear and colored plastic pieces were the most common type found in both opah species (Choy \& Drazen 2013) and we speculate that owing to the large numbers and high frequencies of ingestion, these pieces may have been mistaken for slow-moving gelatinous or translucent prey. Both opah species did in fact feed on a variety of these types of slow-moving prey, including salps, pyrosomes, the cnidarian Atolla sp., and the transparent and translucent jelly-like octopus Japetella diaphana. Salp houses, the gelatinous hosts of hyperiid amphipods such as Phronima and Phrosina were also found in the stomachs of the opah, as well as at least 5 species of the hyperiid amphipods themselves.

\section{Diet of snake mackerel}

To date, the food habits of snake mackerel have not been described in the peer-reviewed literature. Nakamura \& Parin (1993) stated that snake mackerel diet consists of a variety of fishes (myctophids, exocoetids, sauries, scombrids), squids, and crustaceans and describe snake mackerel as vertically migrating to feed in surface waters at night. With regards to crustaceans and some of the fishes, results from the present study are in contrast to observations by Nakamura \& Parin (1993). Crustaceans appear to be a minor dietary component as only a single crustacean prey item was found (Oplophorus gracilirostris). Additionally, no myctophid or scombrid fishes were consumed by snake mackerel in this study. Instead, snake mackerel in the NPSG appear to prey on a mix of epipelagic (bramids, exocoetids, molids) and mesopelagic fishes (paralepidids and gempylids), as well as ommas- trephid and onychoteuthid squids, among others. Notably, all of these prey items are shallow-dwelling and/or quite mobile and fast moving.

Almost half of the snake mackerel examined in this study were without stomach contents. Many of the prey examined were in advanced digestive states (3 or 4, lacking skin and soft parts partially digested). The other gempylid predator, Smith's escolar, was almost always without stomach contents ( $>90 \%$ of stomachs empty). We were able to examine the majority of these specimens whole and can rule out the possibilities of stomach eversion or regurgitation to explain the high incidence of empty stomachs for these 2 gempylids. Rapid digestion rates in these species are a possibility considering the sampling nature. Fishery observers processed samples and as these are low value (escolar) or discarded species (snake mackerel) they would be low sampling priority and may have been left unattended for unknown periods of time, enhancing digestion effects. Direct metabolic estimates are unavailable for either of these species, but similar highly mobile fish species are known to have high metabolisms and thus rapid digestion rates (e.g. yellowfin tuna: Olson \& Boggs 1986; southern bluefin tuna: Young et al. 1997). Both escolar and snake mackerel have morphological characteristics indicative of high mobility (e.g. scutes, caudal keel, streamlined and fusiform bodies). Future work is needed to expand the diet descriptions of both gempylid species, and consideration should be taken towards alternative collection methods (e.g. formalin preservation at sea).

\section{Diet of lancetfish}

Lancetfish is the only species in this study with existing detailed food habits work reported from the Indian, Pacific, and Atlantic oceans (e.g. Haedrich \& Nielsen 1966, Kubota \& Uyeno 1970, Okutani \& Tsukada 1988). Past studies have suggested that consumption of broad ranges of prey types (i.e. ecologically and morphometrically diverse) means that lancetfish is a non-selective, highly opportunistic predator. Lancetfish in this study also demonstrated very broad prey consumption, with the highest number of prey taxa identified (Table S1 in the Supplement), encompassing the largest number of functional groups (Fig. 2A,B). In the closest regional lancetfish diet study, Moteki et al. (1993) found contrasting diets in offshore Hawaiian (central North Pacific) and equatorial Pacific Ocean lancetfish. Hawaiian lancetfish diet consisted primarily of crus- 
taceans (hyperiid amphipods) and mesopelagic fishes, while equatorial lancetfish diet was predominantly mesopelagic fishes with almost no midwater crustaceans (Moteki et al. 1993). Our updated central North Pacific results agreed well with Moteki et al. (1993) in that the same 3 genera of hyperiid amphipods (Phrosina, Phronima, Platyscelus) encompassed $37 \%$ of all prey items by numbers, slightly lower than the $57.8 \%$ numerical composition reported by Moteki et al. (1993). Mesopelagic fishes encompassed nearly $25 \%$ of all prey items by numbers, especially smaller size classes of alepisaurids and sternoptychids. Taxonomic composition of mesopelagic fish prey agreed well with Moteki et al. (1993), but lancetfish from this study consumed more mesopelagic fish overall $(\sim 25 \% \mathrm{~N}$ vs. $\sim 10 \% \mathrm{~N})$. In contrast to past studies describing lancetfish as a non-selective, opportunistic predator, our results suggest that lancetfish is quite a selective feeder over large oceanic regions. Lancetfish diet in this study includes a diversity of prey from fish, cephalopod, and crustacean groups, but the tight agreement of the most important prey at the genus and species levels (in terms of relative proportions of $\% \mathrm{~N}, \% \mathrm{~W}, \% \mathrm{~F}$ ) to studies in other areas of the Pacific Ocean (e.g. Haedrich \& Nielsen 1966, Moteki et al. 1993) suggest targeted hunting. Furthermore, if lancetfish were truly non-selective predators, predation on the most abundant prey in the environment would be expected. This is not the case, as the most abundant mesopelagic micronekton identified from regional midwater trawling studies were largely absent from lancetfish diet (e.g. myctophid and gonostomatid fishes, penaeid and caridean shrimps; Maynard et al. 1975, Drazen et al. 2011).

Interestingly, while fishes were the dominant prey type (by mass) for all predators in this study, none of the species appeared to prey on biomass dominants identified from trawls. Other fish biomass dominants include those from the families Phosichthyidae, Sternoptychidae, and Stomiidae, of which only sternoptychids were consumed by lancetfish and big-eye opah. At a coarse level this suggests that the predators in this study select their prey in disproportion to abundance. Alternatively, myctophids and gonostomatids among others, may somehow evade capture by the predators but not by nets. Faster-moving mesopelagic fishes such as paralepidids, alepisaurids, and scombrolacids not captured in large numbers by trawls were captured by these predators. The same is generally true for crustaceans (euphausiids, oplophorids, penaeids, sergestids) and cephalopods (cranchiids, enoploteuthids, pyrotuethids), where bio- mass dominants from trawls are not important prey items of these predators (Maynard et al. 1975, De Forest \& Drazen 2009). The combination of prey evasion and selective predation results in, at times, contrasting interpretations of pelagic animal abundance.

\section{Ecological niche partitioning among pelagic predators}

The fish sampled for this study were collected across a large area of the NPSG. Within a predator species, samples were distributed highly evenly across this large area but rather unevenly across multiple years and seasons due to opportunistic sampling; the exceptions were the 2 opah species for which catch locations were largely unavailable. For these reasons the ability to detect spatial, seasonal, or interannual differences in diet was rather limited. We were however, able to provide the first diet descriptions of several species integrated over both space and time. Both temporal and spatial differences in pelagic predatory fish diet have been reported (e.g. common dolphinfish: Olson \& Galván-Magaña 2002; yellowfin tuna: Kuhnert et al. 2012; broadbill swordfish: Watanabe et al. 2009), thus further investigation is merited, but we believe our results capture the general feeding habits of these predator species in the NPSG region.

Ecological niche segregation through resource partitioning has been previously observed among large pelagic fishes (e.g. Potier et al. 2007a, Pusineri et al. 2008, Young et al. 2010). Our diet data suggest that these mid-trophic mesopelagic predators also occupy unique ecological niches in the NPSG pelagic ecosystem that can be explained by a combination of differences in functional types of prey exploited, habitat depth, and predator size (as mass).

There are clear differences in the functional types of prey exploited by each of the predators. Lancetfish, for example, consume high numbers of micronekton fishes (e.g. Sternoptyx spp. or hatchetfishes) and hyperiid amphipods (e.g. Phrosina, Phronima) with limited or slow mobility. Gelatinous hosts of these amphipods were also found, as well as high numbers of alicopid polychaete worms and balloonlike cranchiid squids. Snake mackerel on the other hand exploit more mobile fishes and squids (e.g. flying fish, bramids). Some of the important squids exploited by snake mackerel are robust, muscular species from the families Ommastrephidae (e.g. Sthenoteuthis oualaniensis, Ommastrephes bartramii) and Onychoteuthidae, which may be consumed in sur- 
face waters at night. The 2 opah species seem to exploit functional prey groups that are somewhat intermediary to those exploited by lancetfish and snake mackerel, focusing on both slow-moving gelatinous-like prey and on faster-moving organisms. Mobile, deeper-water paralepidids and lancetfish are important prey for big-eye opah, while small-eye opah consume mobile bramids and lancetfish. Both opah species also feed to large degrees on slowmoving bolitaenid octopods (with gelatinous bodies and short arms), pyrosomes, and a different suite of hyperiid amphipods (Playscelus armatus, P. ovoides). Weakly muscled histioteuthid and cranchiid squids were also consumed by big-eye opah, and to a lesser degree by small-eye opah.

Differences in vertical habitat use could be another important way of reducing interspecific competition, however the typical vertical habitats of these 5 species remain unclear. The majority of lancetfish (91\%) and snake mackerel (80\%) were caught on deep longline sets ( 250 m; Bigelow et al. 2006), while half of escolar specimens were caught on deep sets and half on shallow sets $(\sim 0$ to $100 \mathrm{~m})$. Longline-set information was not available for the opah species, but opah are known to be caught more frequently on deep sets ( $\mathrm{P}$. Kleiber pers. comm.). This catch information along with limited tagging information (Kerstetter et al. 2008, Polovina et al. 2008) suggests that large portions of the epipelagic and upper-mesopelagic zones are commonly utilized by the 5 species. However, in combination with differences in the types of functional prey exploited by these predators, niche separation appears to occur partially by depth. For example, many of the mobile fish prey consumed by snake mackerel are strictly epipelagic (bramids, flying fish, molids), while many of the micronekton fish consumed by big-eye opah reside in deeper mesopelagic waters (paralepidids, scopelarchids). These observations agree with available electronic tagging data, which show that opah makes regular vertical excursions throughout the mesopelagic zone, diving to depths at least as deep as $736 \mathrm{~m}$ (Polovina et al. 2008). Unfortunately, we were unable to examine potential diel differences in feeding due to a lack of information on time of capture, especially for the opah species. Potential diel differences in feeding should be addressed in future studies, especially because the comparative use of raw prey weights could introduce a bias to dietary interpretations if species are captured differentially during the day and night or if digestive rates differ between prey types.

Pelagic fish are gape-limited predators and thus fish size may also explain some aspects of the ob- served niche partitioning. Table 1 shows that despite considerable overlap in fish lengths, differences in body forms translate to distinct inter-specific mass differences that would certainly influence predation. Snake mackerel are the smallest of these mesopelagic predators (1.3 kg mean mass) and in terms of PSI values had the least similar diet to the other predators. The 2 opah species on the other hand have similar average masses and had the most similar diets. Clearly diet similarity was not wholly determined by size because lancetfish (mean mass $1.8 \mathrm{~kg}$ ) has substantial diet overlap with big-eye opah. Size-based differences in diet within a species were also observed for both lancetfish and big-eye opah and are another form of resource partitioning. Larger prey (especially fishes and squids) became more important with increasing size for both species, with a shift away from smaller, mostly crustacean-like prey. Shifts in diet with size similar to those observed for lancetfish and big-eye opah have been observed in other pelagic fishes (Olson \& Galván-Magaña 2002, Graham et al. 2007) and imply intraspecific increases in trophic level with size as well as shifts in predation impacts on prey communities.

Despite vertical habitat overlap with other large commercially harvested pelagic fishes, there does not appear to be substantial overlap in the diets of these mesopelagic fishes with the diets of adult size classes of other predatory pelagic fishes. For example, shallow-dwelling billfish such as blue marlin Makaira nigricans consume surface-dwelling fishes such as small tunas and coryphaenids, as well as larval and juvenile fishes and crustaceans (Brock 1984). Deeper-diving broadbill swordfish Xiphias gladius feed narrowly on much larger size classes of ommastrephid and onychoteuthid cephalopods (Ommastrephes bartramii and Sthenoteuthis oualaniensis, 300 to $500 \mathrm{~mm} \mathrm{ML}$ ) and large finfish (the bramids Brama japonica and B. orcini) (Watanabe et al. 2009, B. Mundy pers. comm.). Adult size classes of bigeye tuna Thunnus obesus (mesopelagic divers) and yellowfin tuna $T$. albacares (epipelagic, but capable of deep dives) on the other hand exploit the deep scattering layer of micronekton organisms, focusing on large oplophorid shrimps (e.g. Oplophorus gracilirostris), as well as pelagic juvenile stages of reef teleosts, a host of mesopelagic fishes and cephalopods, and other large epipelagic fishes (e.g. tetraodontiformes) (King \& Ikehara 1956, Graham et al. 2007). In terms of certain mesopelagic fishes (bramids, sternoptychids) and cephalopods (ommastrephids, cranchiids), there is some amount of overlap between the diets of these tunas with the 2 opah 
species in this study, however important differences exist. For example, both tuna species frequently consume large numbers of shallow-dwelling juvenile reef teleosts, crab megalops, and stomatopod crustaceans (King \& Ikehara 1956), all of which the 2 opah species do not.

Differences in feeding by large pelagic fishes can be attributed to differences in physiology, average body size, and gape, among other things (Magnuson \& Heitz 1971). For example, large swordfish can tolerate depleted oxygen levels and perform extensive DVMs to $600 \mathrm{~m}$ and below (Abecassis et al. 2012). Bigeye tuna in the central North Pacific also perform regular dives, occupying 0 to 50 and 300 to $400 \mathrm{~m}$ ranges during the day and 0 to $100 \mathrm{~m}$ at night (Howell et al. 2010), while yellowfin tuna generally remain above the thermocline (Brill et al. 1999). Opah are known to utilize cranial endothermy to dive and access deep waters of the mesopelagic habitat (Runcie et al. 2009). Together, species-specific differences in ecology, physiology, and body size probably allow tunas, billfishes, and mesopelagic predators from this study to reduce competition and coexist in a resource-limited oligotrophic pelagic system.

Acknowledgements. This research was funded by the Pelagic Fisheries Research Program via Cooperative Agreement NA09OAR4320075 between the Joint Institute for Marine and Atmospheric Research and the National Oceanic and Atmospheric Administration. The authors are indebted to the observers of the Pacific Islands Regional Observer Program who work tirelessly to collect quality scientific samples. We also thank K. Busscher, L. Jantz, M. Burns, R. Humphreys, D. Curran, and D. Hawn of NOAA for assistance with sample collection and observer data. J. Muir, D. Itano, A. Gray, B. Takenaka, S. Lee, and H. Tibayan assisted with sample collection. Garden and Valley Isle Seafood, Honolulu Fish Co., and Fresh Island Fish provided opah samples. R. Young, B. Mundy, and M. Wicksten provided patient and expert assistance in taxonomic identifications. J. Hyde and A. Vetter did opah genetic identifications. We thank E. Aus and B. Drake for help with samples and V. Moriwake for database assistance. R. Olson, L. Duffy, J. Polovina, M. Abecassis, T. Sutton, V. Allain, C. Sanchez, A. Neuheimer, M. Merrifield, and D. Lau provided additional support. This manuscript was significantly improved with the help of 3 anonymous reviewers. The views expressed herein are those of the authors and do not necessarily reflect the views of NOAA or any of its subdivisions. This study was carried out in accordance with the animal use protocols of the University of Hawai'i (protocol \#10-984). This is SOEST contribution number 8993.

\section{LITERATURE CITED}

Abecassis M, Dewar H, Hawn D, Polovina J (2012) Modeling swordfish daytime vertical habitat in the North Pacific Ocean from pop-up archival tags. Mar Ecol Prog Ser 452: 219-236
Bigelow K, Musyl MK, Poisson F, Kleiber P (2006) Pelagic longline gear depth and shoaling. Fish Res 77:173-183

Boggs CH, Ito RY (1993) Hawaii's pelagic fisheries. Mar Fish Rev 55:69-82

$>$ Brill RW, Block BA, Boggs CH, Bigelow KA, Freund EV, Marcinek DJ (1999) Horizontal movements and depth distribution of large adult yellowfin tuna (Thunnus albacares) near the Hawaiian Islands, recorded using ultrasonic telemetry: implications for the physiological ecology of pelagic fishes. Mar Biol 133:395-408

Brock RE (1984) A contribution to the trophic biology of the blue marlin (Makaira nigricans Lacepede, 1802) in Hawaii. Pac Sci 38:141-149

Carpenter KE, Niem VH (1999a) FAO species identification guide for fishery purposes: the living marine resources of the western central Pacific. Vol 3: Batoid fishes, chimaeras and bony fishes part 1 (Elopidae to Linophrynidae). FAO, Rome

Carpenter KE, Niem VH (1999b) FAO species identification guide for fishery purposes: the living marine resources of the western central Pacific. Vol 4: Bony fishes part 2 (Mugilidae to Carangidae). FAO, Rome

Carpenter KE, Niem VH (2001a) FAO species identification guide for fishery purposes: the living marine resources of the western central Pacific. Vol 5: Bony fishes part 3 (Menidae to Pomacentridae). FAO, Rome

Carpenter KE, Niem VH (2001b) FAO species identification guide for fishery purposes: the living marine resources of the western central Pacific. Vol 6: Bony fishes part 4 (Labridae to Latimeriidae), estuarine crocodiles, sea turtles, sea snakes, and marine mammals. FAO, Rome

Cherel Y, Sabatié R, Potier M, Marsac F, Ménard F (2007) New information from fish diets on the importance of glassy flying squid (Hyaloteuthis pelagica) (Teuthoidea: Ommastrephidae) in the epipelagic cephalopod community of the tropical Atlantic Ocean. Fish Bull 105: $147-152$

Choy CA (2008) Mercury levels in Hawaiian predatory pelagic fishes and their prey as a function of depth and ecology. MSc thesis, University of Hawaii at Manoa, Honolulu, HI

> Choy CA, Drazen JC (2013) Plastic for dinner? Observations of frequent debris ingestion by pelagic predatory fishes from the central North Pacific. Mar Ecol Prog Ser 485: 155-163

> Choy CA, Popp BN, Kaneko J, Drazen JC (2009) The influence of depth on mercury levels in pelagic fishes and their prey. Proc Natl Acad Sci USA 106:13865-13869

Clarke MR (1986) A handbook for the identification of cephalopod beaks. Clarendon Press, Oxford

Costello M (1990) Predator feeding strategy and prey importance: a new graphical analysis. J Fish Biol 36:261-263

De Forest L, Drazen J (2009) The influence of a Hawaiian seamount on mesopelagic micronekton. Deep-Sea Res I 56:232-250

> Drazen JC, De Forest LG, Domokos R (2011) Micronekton abundance and biomass in Hawaiian waters as influenced by seamounts, eddies, and the moon. Deep-Sea Res I 58:557-566

> Graham BS, Grubbs D, Holland K, Popp BN (2007) A rapid ontogenetic shift in the diet of juvenile yellowfin tuna from Hawaii. Mar Biol 150:647-658

Haedrich RL, Nielsen JG (1966) Fishes eaten by Alepisarus (Pisces, Iniomi) in the southeastern Pacific Ocean. DeepSea Res 13:909-919 
Hawn DR, Collette BB (2012) What are the maximum size and live body coloration of opah (Teleostei: Lampridae: Lampris species)? Ichthyol Res 59:272-275

Howell EA, Hawn DR, Polovina JJ (2010) Spatiotemporal variability in bigeye tuna (Thunnus obesus) dive behavior in the central North Pacific Ocean. Prog Oceanogr 86: 81-93

> Hurlbert SH (1978) The measurement of niche overlap and some relatives. Ecology 59:67-77

> Ivanova NV, Zemlak TS, Hanner RH, Hebert PD (2007) Universal primer cocktails for fish DNA barcoding. Mol Ecol Notes 7:544-548

> Jackson GD, Shaw AGP, Lalas C (2000a) Distribution and biomass of two squid species off southern New Zealand: Nototodarus sloanii and Moroteuthis ingens. Polar Biol 23:699-705

> Jackson GD, Buxton NG, George MJA (2000b) Diet of the southern opah Lampris immaculatus on the Patagonian Shelf; the significance of the squid Moroteuthis ingens and anthropogenic plastic. Mar Ecol Prog Ser 206:261-271

Kerstetter DW, Rice PH, Snodgrass D, Prince ED (2008) Behavior of an escolar Lepidocybium flavobrunneum in the windward passage as determined by popup satellite tagging archival tagging. Gulf Caribb Res 20:97-102

King JE, Ikehara II (1956) Comparative study of food of bigeye and yellowfin tuna in the central Pacific. Fish Bull 57: 61-87

Kubota T, Uyeno T (1970) Food habits of lancetfish Alepisaurus ferox (order Myctophiformes) in Suruga Bay, Japan. Jpn J Ichthyol 17:22-28

Kuhnert PM, Duffy LM, Young JW, Olson RJ (2012) Predicting fish diet composition using a bagged classification tree approach: a case study using yellowfin tuna (Thunnus albacares). Mar Biol 159:87-100

Magnuson JJ, Heitz JG (1971) Gill raker apparatus and food selectivity among mackerels, tunas, and dolphins. Fish Bull 69:361-370

Maynard SD, Riggs FV, Walters J (1975) Mesopelagic micronekton in Hawaiian waters: faunal composition, standing stock, and diel vertical migration. Fish Bull 73:726-736

Moteki M, Fujita K, Kohno H (1993) Stomach contents of the longnose lancetfish, Alepisaurus ferox, in Hawaiian and central equatorial Pacific waters. J Tokyo Univ Fish 80: 121-137

Moteki M, Arai M, Tsuchiya K, Okamoto H (2001) Composition of piscine prey in the diet of large pelagic fish in the eastern tropical Pacific Ocean. Fish Sci 67:1063-1074

Mundy BC (2005) Checklist of the fishes of the Hawaiian Archipelago, Vol 6. Bishop Museum Press, Honolulu, HI

Nakabo T (2002) Fishes of Japan: with pictorial keys to the species, Vol 1. Tokai University Press, Tokyo

Nakamura I, Parin NV (1993) FAO species catalogue. Vol 15: Snake mackerels and cutlassfishes of the world (families Gempylidae and Trichiuridae). An annotated and illustrated catalogue of the snake mackerels, snoeks, escolars, gemfishes, sackfishes, domine, oilfish, cutlassfishes, scabbardfishes, hairtails and frostfishes to date. In: FAO (ed) FAO fisheries synopsis. FAO, Rome

Okiyama M (1988) An atlas of the early stage fishes in Japan. Tokai University Press, Tokyo

Okutani T, Tsukada S (1988) Squids eaten by lancetfish (Alepisaurus ferox) and tunas in the tropical Indo-pacific oceans. J Tokyo Univ Fish 75:1-44

> Olson RJ, Boggs CH (1986) Apex predation by yellowfin tuna (Thunnus albacares): independent estimates from gastric evacuation and stomach contents, bioenergetics, and cesium concentrations. Can J Fish Aquat Sci 43: 1760-1775

Olson RJ, Galván-Magaña F (2002) Food habits and consumption rates of common dolphinfish (Coryphaena hippurus) in the eastern Pacific Ocean. Fish Bull 100: 279-298

Polovina JJ, Woodworth-Jefcoats PA (2013) Fisheryinduced changes in the subtropical Pacific pelagic ecosystem size structure: observations and theory. PLoS ONE 8:e62341

> Polovina JJ, Hawn D, Abecassis M (2008) Vertical movement and habitat of opah (Lampris guttatus) in the central North Pacific recorded with pop-up archival tags. Mar Biol 153:257-267

Polovina JJ, Abecassis M, Howell EA, Woodworth P (2009) Increases in the relative abundance of mid-trophic level fishes concurrent with declines in apex predators in the subtropical North Pacific, 1996-2006. Fish Bull 107: 523-531

Potier M, Marsac F, Cherel Y, Lucas V, Sabatié R, Maury O, Ménard F (2007a) Forage fauna in the diet of three large pelagic fishes (lancetfish, swordfish and yellowfin tuna) in the western equatorial Indian Ocean. Fish Res 83: $60-72$

Potier M, Ménard F, Cherel Y, Lorrain A, Sabatié R, Marsac F (2007b) Role of pelagic crustaceans in the diet of the longnose lancetfish Alepisaurus ferox in the Seychelles waters. Afr J Mar Sci 29:113-122

> Pusineri C, Chancollon O, Ringelstein J, Ridoux V (2008) Feedinng niche segregation among the Northeast Atlantic community of oceanic top predators. Mar Ecol Prog Ser 361:21-34

R Development Core Team (2012) R: a language and environment for statistical computing. R Foundation for Statistical Computing, Vienna, available at www. R-project.org

Randall JE (2007) Reef and shore fishes of the Hawaiian Islands. Sea Grant College Program, University of Hawaii, Honolulu, HI

Romanov EV, Ménard F, Zamorov VV, Potier M (2008) Variability in conspecific predation among longnose lancetfish Alepisaurus ferox in the western Indian Ocean. Fish Sci 74:62-68

> Runcie RM, Dewar H, Hawn DR, Frank LR, Dickson KA (2009) Evidence for cranial endothermy in the opah (Lampris guttatus). J Exp Biol 212:461-470

Satoh K (2004) Occurrence of Phronima sedentaria (Forskal, 1775) (Amphipoda, Hyperiidea) in the stomach of the longnose lancetfish, Alepisaurus ferox (Lowe, 1833) (Aulopiformes, Alepisauroidei) in the North and tropical Atlantic Ocean. Crustaceana 77:729-739

Schoener TW (1970) Nonsynchronous spatial overlap of lizards in patchy habitats. Ecology 51:408-418

Smith MM, Heemstra PC (1986) Smiths' sea fishes. Struik Publishers, Cape Town

Tamura K, Dudley J, Nei M, Kumar S (2007) MEGA4: molecular evolutionary genetics analysis (MEGA) software version 4.0. Mol Biol Evol 24:1596-1599

Vinogradov ME, Volkov AF, Semenova TN, Siegel-Causey D (1996) Hyperiid amphipods (Amphipoda, Hyperiidea) of the world oceans. Smithsonian Institution Libraries, Washington, DC

Wallace RK, Ramsey JS (1983) Reliability in measuring diet overlap. Can J Fish Aquat Sci 40:347-351 
Watanabe H, Kubodera T, Yokawa K (2009) Feeding ecology of the swordfish Xiphias gladius in the subtropical region and transition zone of the western North Pacific. Mar Ecol Prog Ser 396:111-122

Wrobel D, Mills C (1998) Pacific coast pelagic invertebrates: a guide to the common gelatinous animals. Sea Challengers, Monterey, CA

Young RE (1978) Vertical distribution and photosensitive vesicles of pelagic cephalopods from Hawaiian waters. Fish Bull 76:583-615

Young JW, Lamb TD, Le D, Bradford RW, Whitelaw AW (1997) Feeding ecology and interannual variations in diet

Editorial responsibility: Matthias Seaman,

Oldendorf/Luhe, Germany of southern bluefin tuna, Thunnus maccoyii, in relation to coastal and oceanic waters off eastern Tasmania, Australia. Environ Biol Fishes 50:275-291

> Young JW, Lansdell MJ, Campbell RA, Cooper SP, Juanes F, Guest MA (2010) Feeding ecology and niche segregation in oceanic top predators off eastern Australia. Mar Biol 157:2347-2368

Young RE, Vecchione M, Mangold KM (2012) Decapodiformes Leach, 1817: squids, cuttlefishes and their relatives, version 04 July 2012. http://tolweb.org/Decapodiformes/19404/2012.07.04 in The Tree of Life Web Project, http://tolweb.org

Submitted: May 6, 2013; Accepted: August 13, 2013 Proofs received from author(s): September 26, 2013 